\title{
ASYMMETRIC SUPPORT TECHNOLOGY FOR GOB SIDE ENTRY RETAINING WITH HIGH WATER MATERIAL
}

\author{
Qiyuan SHAN *, Yongli LIU, Tao LI and Zhupeng JIN
}

School of Mining Engineering, Heilongjiang Institute of Science and Technology, Harbin, Heilongjiang, China

*Corresponding author's e-mail: shanqiyuan1@163.com

\begin{tabular}{l} 
ARTICLE INFO \\
\hline Article history: \\
Received 25 December 2020 \\
Accepted 2 June 2021 \\
Available online 18 June 2021 \\
\hline
\end{tabular}

Keywords:

High water material

Gob side entry retaining

Numerical simulation

Stress distribution

Asymmetric support

\begin{abstract}
The gob side entry retaining with high water material is often used in coal mines. To study the stress evolution characteristics of surrounding rock and asymmetric support control technology of gob side entry retaining with high water material, the evolution law of stress and deformation of surrounding rock in gob side entry retaining during working face mining is studied by theoretical analysis, numerical simulation and field measurement. According to the stress variation of overlying strata during the mining process of the working face, the mechanical models before and after the basic roof fracture were established respectively. The stress and deformation of the filling body and the roof on the side of the filling body are larger, and the stress and deformation of the solid coal and the roof on the side of solid coal are smaller. The maximum stress is at $3 \mathrm{~m}$ away from the roadway. The first weighting step distance is $40 \mathrm{~m}$ and the periodic weighting step distance is $30 \mathrm{~m}$. Based on the stress and deformation characteristics of the roadway surrounding, the roadway surrounding support is divided into filling bodyside, solid coal side, and middle part of roadway roof. The asymmetric support technology of "filling body+ double row hydraulic prop + I-beam + high-strength pretension anchor cable + high-strength bolt" is proposed. The field engineering practice shows that the surrounding rock control effect of asymmetric support technology with high water material is good.
\end{abstract}

\section{INTRODUCTION}

The gob side entry retaining is the use of special materials in the roadway side to construct a roadway protection belt, the retained roadway to serve the next working face (Zhang et al., 2018; Zhang et al., 2019; Zhao, 2019). The gob side entry retaining can realize the Y-type ventilation, effectively solve the problem of gas overrun in the upper corner, and realize gas pre-extraction of adjacent coal seams, which provides a guarantee for safe mining (Zhang and Li, 2019). The roadway along the gob is located in the low-pressure area, the probability of rockburst is greatly reduced; the coal pillar between the adjacent working faces is canceled, the amount of labor is reduced, the coal recovery rate is improved, and it has remarkable economic and social benefits (Chen at al., 2019; Gong et al., 2019; Guo et al., 2019; Han et al., 2018; Han et al., 2019).

The filling materials of gob side entry retaining mainly include concrete block, gangue, coal gangue concrete, paste material, and high water material (Liu et al., 2020; Sun et al., 2020; Vadapalli, et al., 2012). Among them, the high water materials have the advantages of high strength and controllable setting time, which is widely used in coal mines (Bai et al., 2020; Li et al., 2016; Zhao et al., 2015; Doherty et al., 2015; Altunbas et al., 2017).
At present, the main support technology for roadway surrounding rock is hydraulic prop + anchor cable, anchor cable + bolt, hydraulic prop + anchor cable, and other symmetrical support (Chen et al., 2012; Li, 2000; Ma et al., 2011; Miao, 2010; Zhang et al., 2012). Although the symmetrical support of the roadway can maintain the stability of the roadway, it also causes the waste of support materials and the increase of support costs (Fallavena et al., 2018; Skousen, 2017). Therefore, through theoretical analysis and numerical simulation, this paper studied the asymmetry of the stress and displacement of the surrounding rock of gob side entry retaining with high water material, and established the asymmetric support technology, and analyzed the supporting effect.

\section{MECHANICAL MODEL OF GOB SIDE ENTRY RETAINING}

\subsection{BEFORE THE BASIC ROOF COLLAPSE}

With the working face advancing, the roof will bend and sink until the roof breaks (Tang et al., 2011). The direct roof and basic roof above the working face move downward, and the mechanical model of filling body for gob side entry retaining is shown in Figure 1 (Adhikary et al., 2015). 


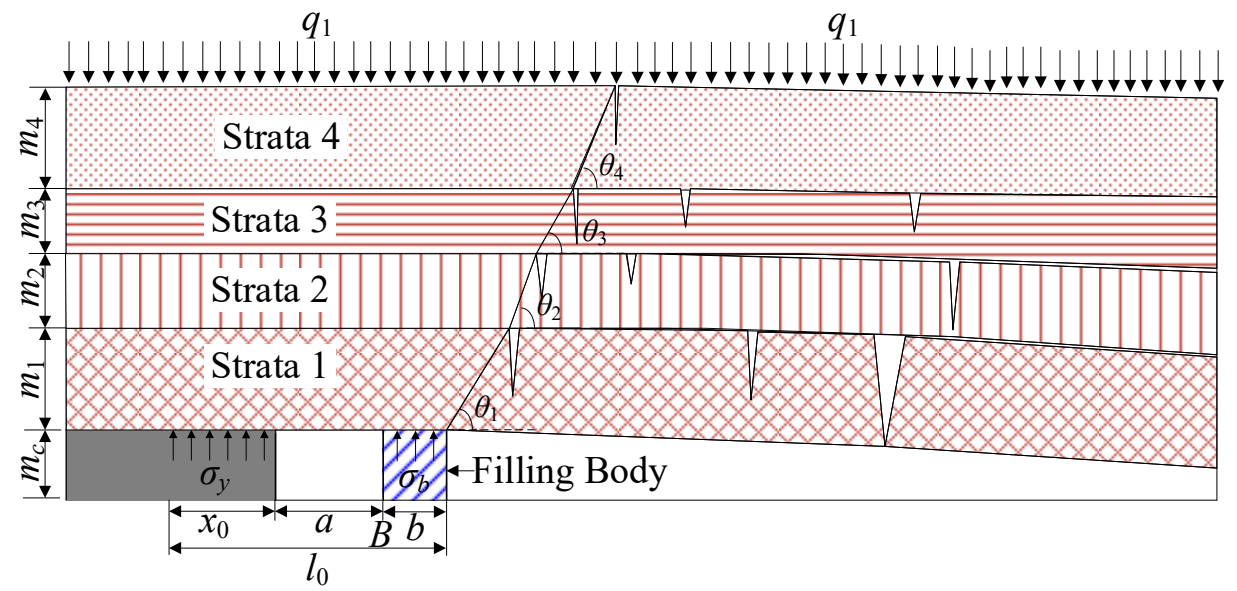

Fig. 1 Mechanical model of gob side entry retaining before the basic roof collapse.

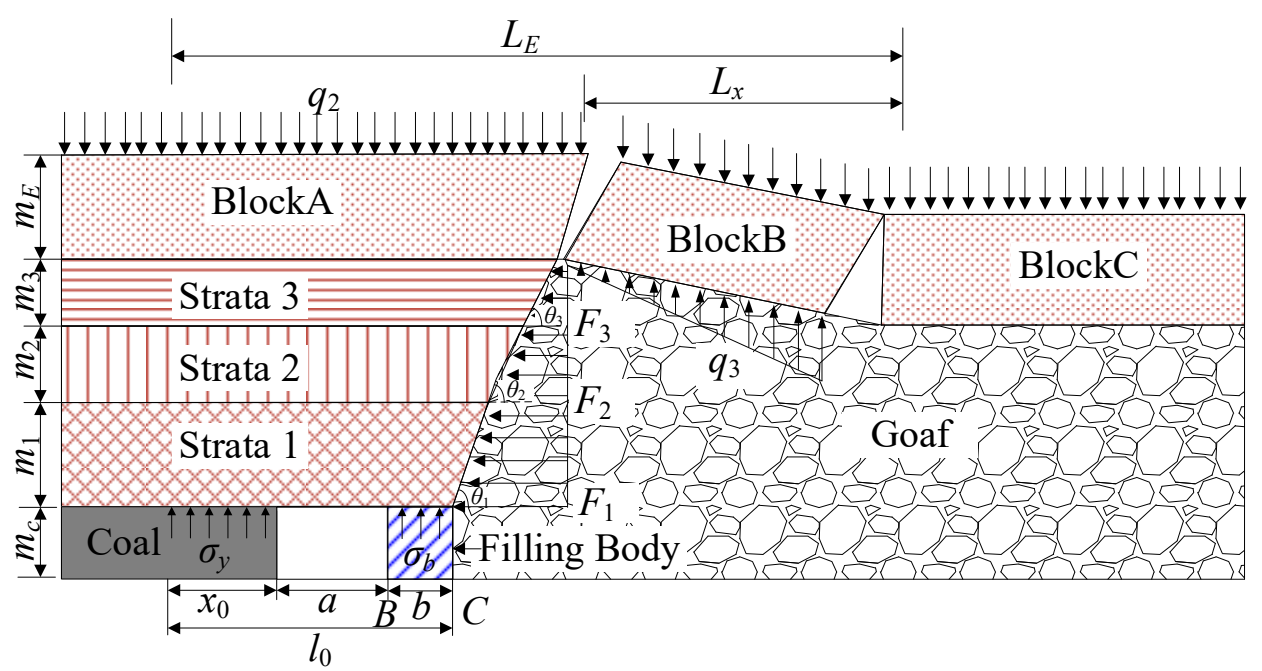

Fig. 2 Mechanical model of gob side entry retaining after the basic roof collapse.

Assuming that the roof pressure is uniformly applied to the filling body beside the roadway, the mechanical equilibrium model equation in the vertical direction is established,

$$
\begin{aligned}
\sigma_{y} x_{0} & +\sigma_{b} b=\gamma_{Z 1} m_{Z 1}\left(I_{0}+m_{Z 1} \cot \frac{\theta_{1}}{2}\right)+\cdots+ \\
& +\left(\gamma_{Z i} m_{Z i}+q_{1}\right)\left(I_{0}+m_{Z(i-1)} \cot \frac{\theta_{Z(i-1)}}{2}+m_{Z i} \cot \frac{\theta_{i}}{2}\right)
\end{aligned}
$$

Where, the $\sigma_{y}$ is the support resistance of solid coal to the roof, $\mathrm{MPa}$; the $x_{0}$ is the width of loose zone of solid coal, $\mathrm{m}$; the $\sigma_{b}$ is the support resistance of filling body, $\mathrm{MPa}$; the $b$ is the filling body width, $\mathrm{m}$; the $\gamma_{Z}$ is the bulk density of the direct roof rock, $\mathrm{kN} / \mathrm{m}^{3}$; the $m_{Z i}$ is the thickness of the $i$-th layer of the direct roof, m; the $\theta_{Z i}$ is the collapse angle of the $i$-th layer in the direct roof, ${ }^{\circ}$; the $m_{F}$ is the thickness of the top coal, $\mathrm{m}$; the $I_{0}$ is the distance from the elastic-plastic junction of the overlying strata to the outside of the filling body beside the roadway, $\mathrm{m}$; the $q_{1}$ is the load of the overlying strata on the fractured strata without lateral fracture, $\mathrm{MPa}$.

$$
\begin{aligned}
& x_{0}=\frac{M}{2 \xi f} \ln \frac{K \gamma H+C \cot \varphi}{\xi C \cot \varphi} \\
& \text { and } \xi=\frac{1+\sin \varphi}{1-\sin \varphi}
\end{aligned}
$$

Where, the $M$ is the average mining thickness, $\mathrm{m}$; the $C$ is the cohesive force of coal, MPa; $f$ is the internal friction angle of the coal seam, $f=\tan \varphi$; the $K$ is the stress concentration coefficient; the $H$ is the buried depth of coal seam, $\mathrm{m}$; the $\gamma$ is the bulk density of roof rock, $\mathrm{kN} / \mathrm{m}^{3}$.

\subsection{AFTER THE BASIC ROOF COLLAPSE}

With the advance of the working face, the roof behind the working face continues to collapse. When the exposed length of the basic roof behind the working face reaches its limit span, the basic roof breaks and compacts the goaf (Chen et al., 2012). At this time, the mechanical model of gob side entry retaining is shown in Figure 2 (Liu et al., 2020).

The mechanical equilibrium model equation in the vertical direction is established, 


\begin{tabular}{|c|c|c|c|}
\hline Columnar & Rock Name & Thickness/m & Lithology Description \\
\hline & $\begin{array}{l}\text { Fine } \\
\text { Sandstone }\end{array}$ & 15.1 & $\begin{array}{l}\text { Black, flat fracture, with a small amount of plant leaves and } \\
\text { siderite nodules. }\end{array}$ \\
\hline & $\begin{array}{l}\text { Coarse } \\
\text { Sandstone }\end{array}$ & 28.5 & $\begin{array}{l}\text { Dark gray, flat fracture, a small number of plant rhizome fossils } \\
\text { and pyrite nodules }\end{array}$ \\
\hline & $\begin{array}{l}\text { Sandy } \\
\text { Conglomerate }\end{array}$ & 33.3 & $\begin{array}{l}\text { Black gray, a small amount of carbonaceous, uneven fracture, } \\
\text { siderite nodules are rare. }\end{array}$ \\
\hline & Siltstone & 15.6 & $\begin{array}{l}\text { Dark gray, with a small amount of pyrite nodules and plant } \\
\text { rhizome fossils. }\end{array}$ \\
\hline & $\begin{array}{l}\text { No.8 Coal } \\
\text { Seam }\end{array}$ & 3.2 & $\begin{array}{l}\text { Black, light and hard. The streaks are brown, mainly bright coal, } \\
\text { followed by Jingmei dark coal, and semi bright briquette. }\end{array}$ \\
\hline$B 80808$ & $\begin{array}{l}\text { Sandy } \\
\text { Mudstone }\end{array}$ & 14.5 & $\begin{array}{l}\text { Gray, mainly composed of quartz, with argillaceous calcareous } \\
\text { cementation. Siltstone and fine sandstone are interbedded with } \\
\text { parallel bedding. }\end{array}$ \\
\hline 38888888. & $\begin{array}{l}\text { Medium } \\
\text { Sandstone }\end{array}$ & 31.8 & $\begin{array}{l}\text { Light gray white, mainly composed of quartz, locally rich in } \\
\text { siderite nodules, rarely carbonaceous stripes with wavy bedding. }\end{array}$ \\
\hline
\end{tabular}

Fig. 3 Columnar chart.

$$
\begin{aligned}
& \sigma_{y} x_{0}+\sigma_{b} b+\frac{F_{1}}{2} m_{Z 1} \tan \theta_{1}+\cdots+\frac{F_{n}}{2} m_{Z n} \tan \theta_{n}+ \\
& +Q_{2}+\frac{q_{3}}{2} L_{x}=\gamma_{Z 1} m_{Z 1}\left(l_{0}+m_{F} \cot \frac{\theta_{0}}{2}+m_{Z 1} \cot \frac{\theta_{1}}{2}\right)+\cdots \\
& +\gamma_{Z i} m_{Z i}\left(l_{0}+m_{Z(i-1)} \cot \frac{\theta_{Z(i-1)}}{2}+m_{Z i} \cot \frac{\theta_{i}}{2}\right)
\end{aligned}
$$

Where, the $Q_{2}$ is the force of block $C$ acting on the vertical direction of rock block $B, \mathrm{kN}$; the $q_{2}$ is the loading of overlying strata on the basic roof, $\mathrm{MPa}$; the $L_{E}$ is the sum of the length of rock beams $A$ and $B$, $\mathrm{m}$; the $\gamma_{E}$ is the bulk density of basic roof, $\mathrm{kN} / \mathrm{m}^{3}$; the $m_{E}$ is the thickness of basic roof, $\mathrm{m}$; the $q_{3}$ is the maximum support resistance of collapse gangue to the roof, $\mathrm{MPa}$; the $L_{x}$ is the horizontal length of block $B$.

\section{PROJECT OVERVIEW}

The buried depth of the No. 3 working face of the eighth floor in Xin'an Coal Mine is $520 \mathrm{~m}$, and the average thickness of the coal seam is $3 \mathrm{~m}$. The direct roof is siltstone with a thickness of $4 \mathrm{~m}$. The basic roof is coarse sandstone with a thickness of $8 \mathrm{~m}$. The direct bottom is fine sandstone with a thickness of $2 \mathrm{~m}$. The fully mechanized mining method is adopted in the working face. The roadway of the gob side entry retaining is the transportation roadway. After retaining the roadway successfully, the transportation roadway will become the return air roadway of the next working face. The columnar chart is shown in Figure 3.

By bringing the relevant parameters of coal seam and overlying strata into (1)-(4), it is concluded that the stress acting on the filling body is greater than that acting on the solid coal. Therefore, an asymmetric stress circle is formed around the surrounding rock of gob side entry retaining with high water material.

There are four kinds of the location of filling body: (1) all the filling body is placed in the goaf; (2) a small part of the filling body is located in the roadway, most of the filling body is in the goaf; (3) the filling body is located in the roadway, a small part of the filling body is placed in the goaf; (4) the whole filling body is in the roadway (Maleki et al., 1986; Huang et al., 2019; Li et al., 2019; Li et al., 2016;). There are the following relations in the width of retained roadway: when the roadway width is large, it is easy to carry out mining work, but it is difficult to maintain under the action of mine pressure; when the roadway width is small, it can not meet the work requirements, it is necessary to expand the slope, which brings heavy physical labor to workers (Haeamy et al., 1990; Li et al., 2020). Through the comprehensive analysis of the surrounding rock characteristics and the standards of return air roadway and transportation roadway, it is concluded that the filling body construction sites are all carried out in the roadway. The schematic diagram of the gob side entry retaining is shown in Figure 4.

The high water material used in Xin'an Coal Mine is composed of fly ash, fluidic agent, early strength agent and accelerator, gypsum, and coal gangue, the water-cement ratio is greater than 3 . The high water material and water are stirred and solidified to form the filling body. The strength of the filling body can reach $4 \mathrm{MPa}$ within 8 hours and then increase gradually with the age. As time increases, the strength of the filling body can finally reach $50 \mathrm{MPa}$ on the $28^{\text {th }}$ day, which meets the technical requirements for the gob-side entry retaining. The mechanical parameters of the filling body are shown in Table 1. 


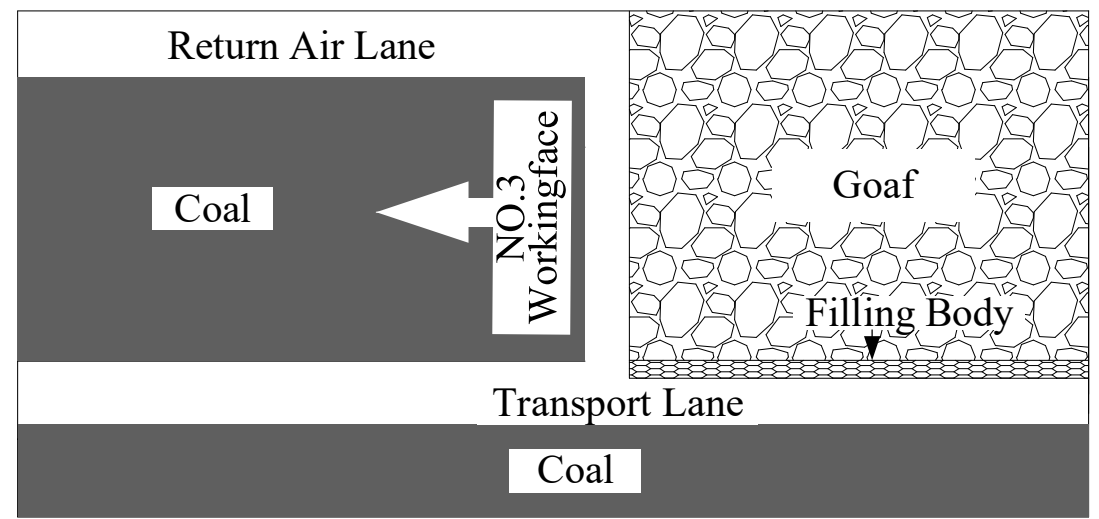

Fig. 4 Schematic diagram of gob side entry retaining.

Table 1 Mechanical parameters of the filling body.

\begin{tabular}{ccccccc}
\hline Lithology & $\begin{array}{c}\text { Bulk } \\
\text { Modulus/GPa }\end{array}$ & $\begin{array}{c}\text { Shear } \\
\text { Modulus/GPa }\end{array}$ & $\begin{array}{c}\text { Density/ } \\
\left(\mathrm{kg} / \mathrm{m}^{3}\right)\end{array}$ & $\begin{array}{c}\text { Friction } \\
\text { Angle/ }\left({ }^{\circ}\right)\end{array}$ & $\begin{array}{c}\text { Cohesion/ } \\
\mathrm{MPa}\end{array}$ & $\begin{array}{c}\text { Tensile } \\
\text { Strength/MPa }\end{array}$ \\
\hline Filling body & $6.1 \sim 7.9$ & $2.7 \sim 3.5$ & $14 \sim 21$ & $31 \sim 52$ & $2.2 \sim 3.2$ & $1.4 \sim 2.6$ \\
\hline
\end{tabular}

Table 2 Mechanical parameters of the various strata.

\begin{tabular}{|c|c|c|c|c|c|c|}
\hline Lithology & $\begin{array}{c}\text { Bulk } \\
\text { Modulus/GPa }\end{array}$ & $\begin{array}{c}\text { Shear } \\
\text { Modulus/ } \\
\text { GPa }\end{array}$ & $\begin{array}{l}\text { Density/ } \\
(\mathrm{kg} / \mathrm{m})\end{array}$ & $\begin{array}{c}\text { Friction } \\
\text { Angle/ } \\
\left(0^{\circ}\right)\end{array}$ & $\begin{array}{c}\text { Cohesion/ } \\
\mathrm{MPa}\end{array}$ & $\begin{array}{c}\text { Tensile } \\
\text { Strength/MPa }\end{array}$ \\
\hline Siltstone & 5.2 & 2.8 & 2300 & 36 & 3.7 & 1.9 \\
\hline Medium Sandstone & 4.1 & 4.2 & 2000 & 35 & 2.8 & 2.6 \\
\hline Coal & 1.6 & 1.5 & 1400 & 24 & 1.2 & 1.3 \\
\hline Gritstone & 5.2 & 5.3 & 2400 & 34 & 2.3 & 2.7 \\
\hline Mudstone & 8.1 & 3.2 & 3000 & 24 & 2.7 & 1.6 \\
\hline
\end{tabular}

\section{NUMERICAL SIMULATION \\ 3.1. MODELING}

According to the geological conditions No. 3 working face of the eighth floor in Xin'an Coal Mine, the FLAC ${ }^{3 \mathrm{D}}$ numerical simulation software is used to analyze the stress and deformation evolution law of surrounding rock. The model boundary is set according to the influence area of roadway and working face mining so that the boundary constraints do not affect the stress distribution inside the numerical model. So, the size of the model is $200 \mathrm{~m} \times 150 \mathrm{~m} \times 85 \mathrm{~m}$ in length $\times$ width $\times$ height. The load corresponding to the weight of overlying strata is applied to the upper part of the model. The horizontal displacement around the model and the vertical displacement at the bottom are constrained. The mechanical parameters of each rock stratum are shown in Table 2.

The length of the working face is $135 \mathrm{~m}$, and the dimensions of the return air roadway and the transportation roadway are both $5 \mathrm{~m} \times 5 \mathrm{~m}$. The transportation roadway near the goaf will be the return air roadway of the next working face. The working face is pushed forward by $10 \mathrm{~m}$, and the back of the working face is filled once. The width of the filling body is 3 meters and the length is 10 meters. The Mohr-Coulomb model is adopted for filling body and coal seam. The model structure is shown in Figure 5.

\subsection{THE DISTRIBUTION CHARACTERISTICS OF STRESS}

To better simulate the working face filling, the method of step-by-step filling is adopted to simulate the working face of one mining and one filling, that is, the working face is filled with $10 \mathrm{~m}$ every $10 \mathrm{~m}$ mining. The stress and displacement of the roof, floor, solid coal and filling body are monitored when the working face is in different positions. The stress distribution program of the surrounding rock of the retained roadway is analyzed under different advancing distances, and the temporal and spatial evolution law of the stress distribution of the surrounding rock is revealed, which provides a reference for the control of the surrounding rock of the roadway.

The stress distribution is shown in Figure 6. It can be seen from the figures that the stress acting on the filling body is greater than that acting on the solid coal due to the influence of working face mining. When the working face is pushed forward $10 \mathrm{~m}$, the stress near the working face is low, mainly because the overlying strata of the goaf begin to separate, and no large stress concentration is formed. In the process of the working face advancing from $20 \mathrm{~m}$ to $40 \mathrm{~m}$, the stress in front of and on both sides of the working face increases gradually. With the advancing of the working face, the stress near the working face tends to be stable gradually. 


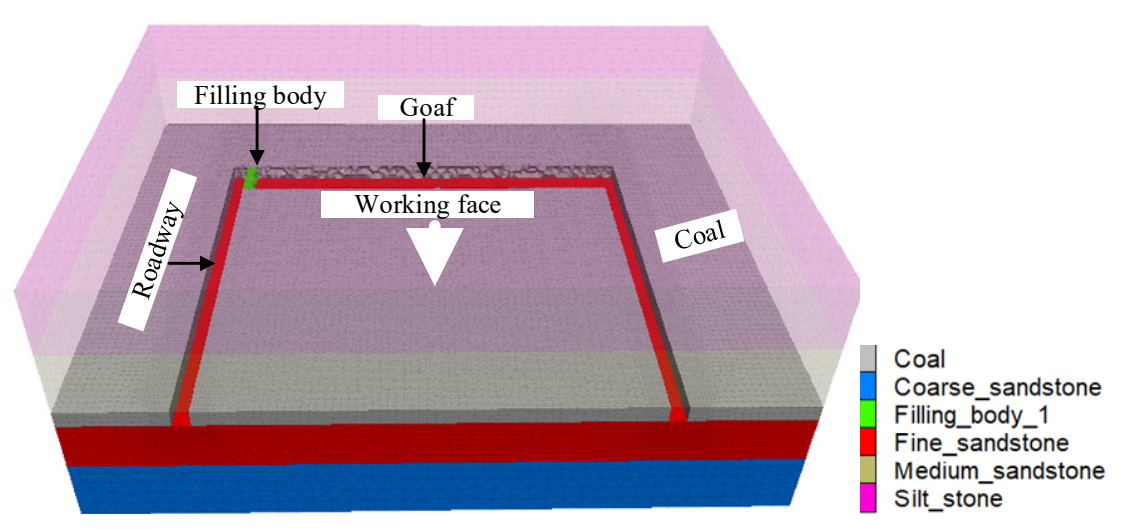

Fig. 5 The structure of the numerical simulation model.

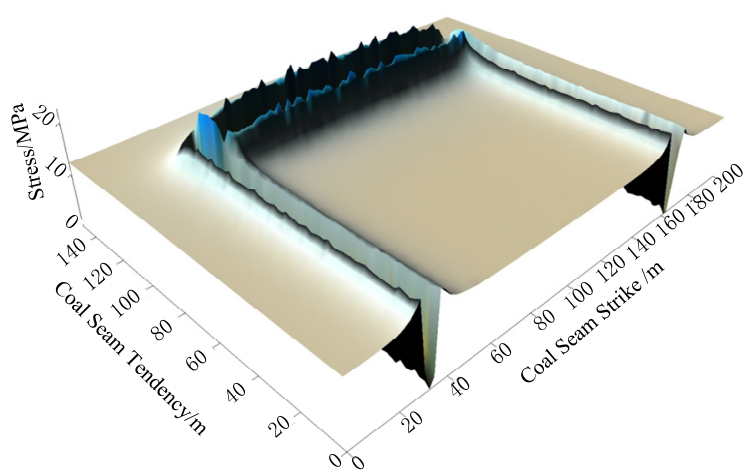

(a) Advance $10 \mathrm{~m}$

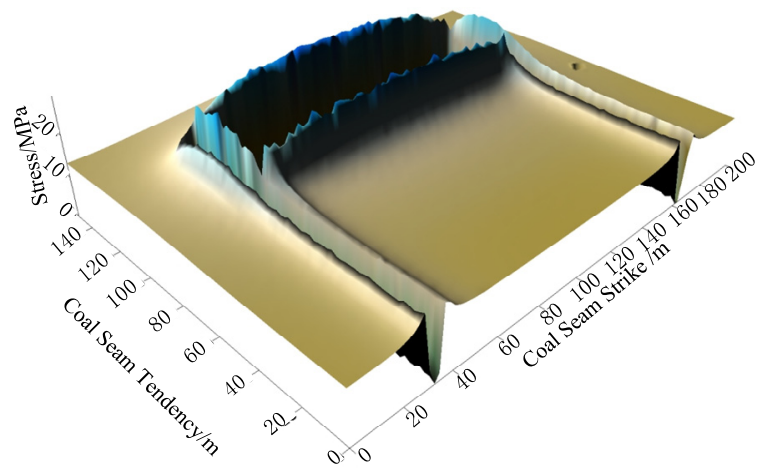

(c) Advance $30 \mathrm{~m}$

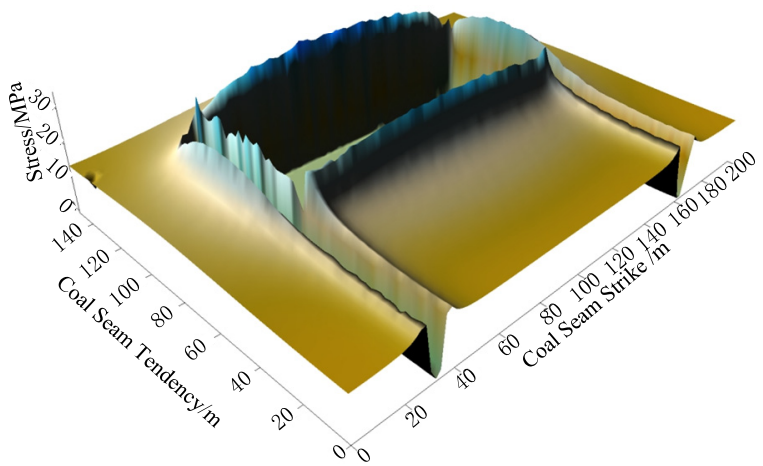

(e) Advance $50 \mathrm{~m}$

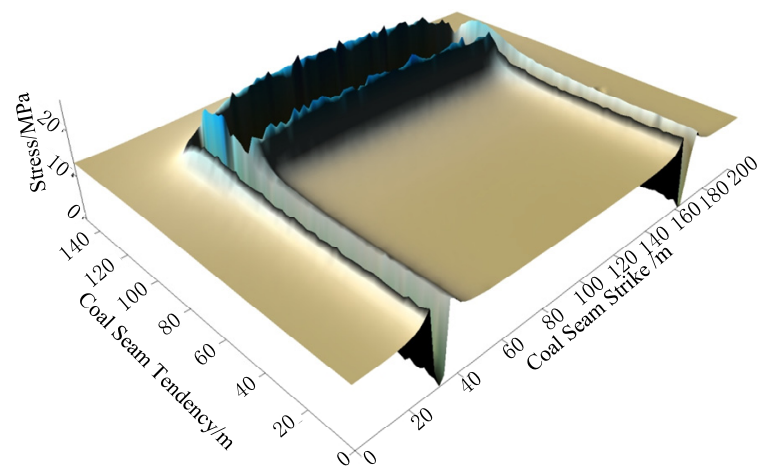

(b) Advanced $20 \mathrm{~m}$

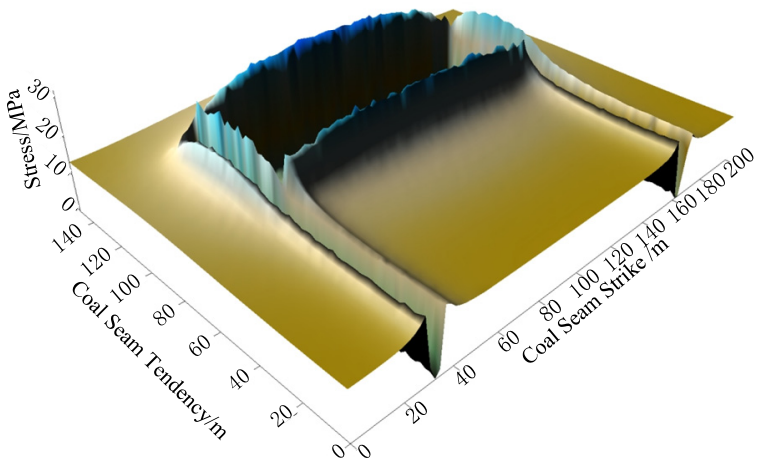

(d) Advanced $40 \mathrm{~m}$

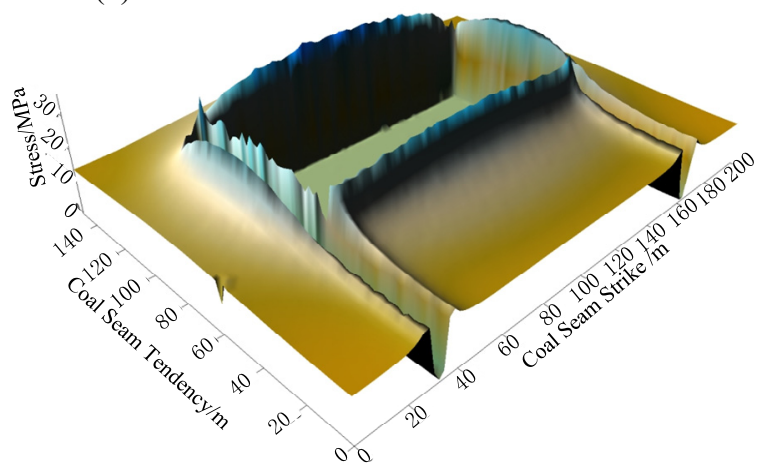

(f) Advanced $60 \mathrm{~m}$ 


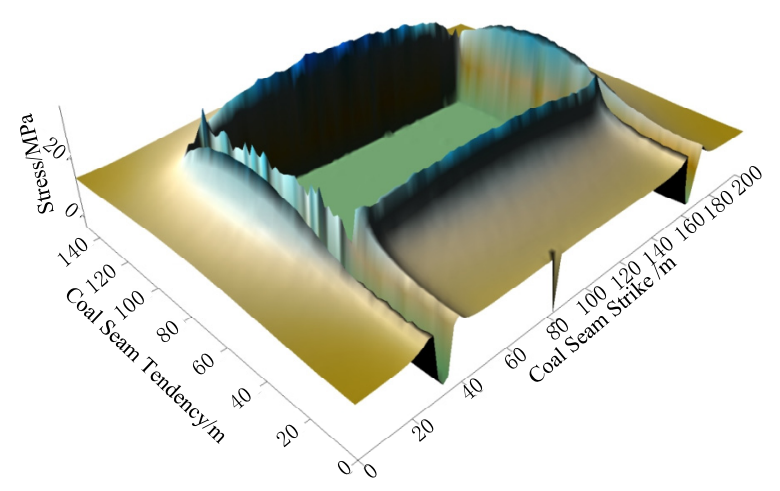

g) Advance $70 \mathrm{~m}$

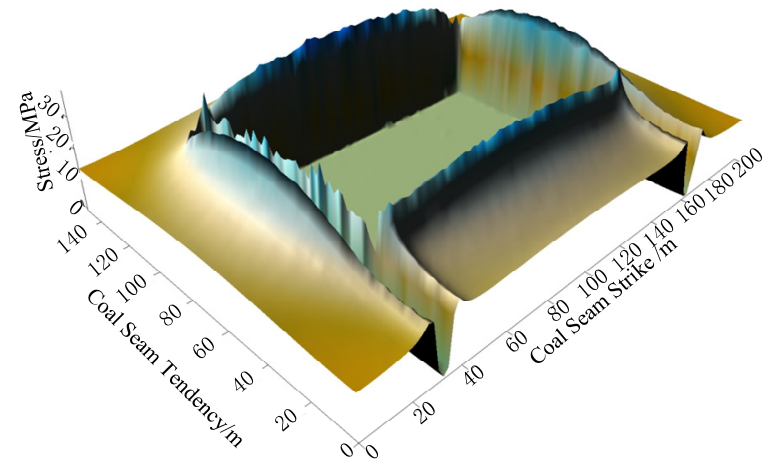

(h) Advanced $80 \mathrm{~m}$

Fig. 6 Stress distribution near the working face.
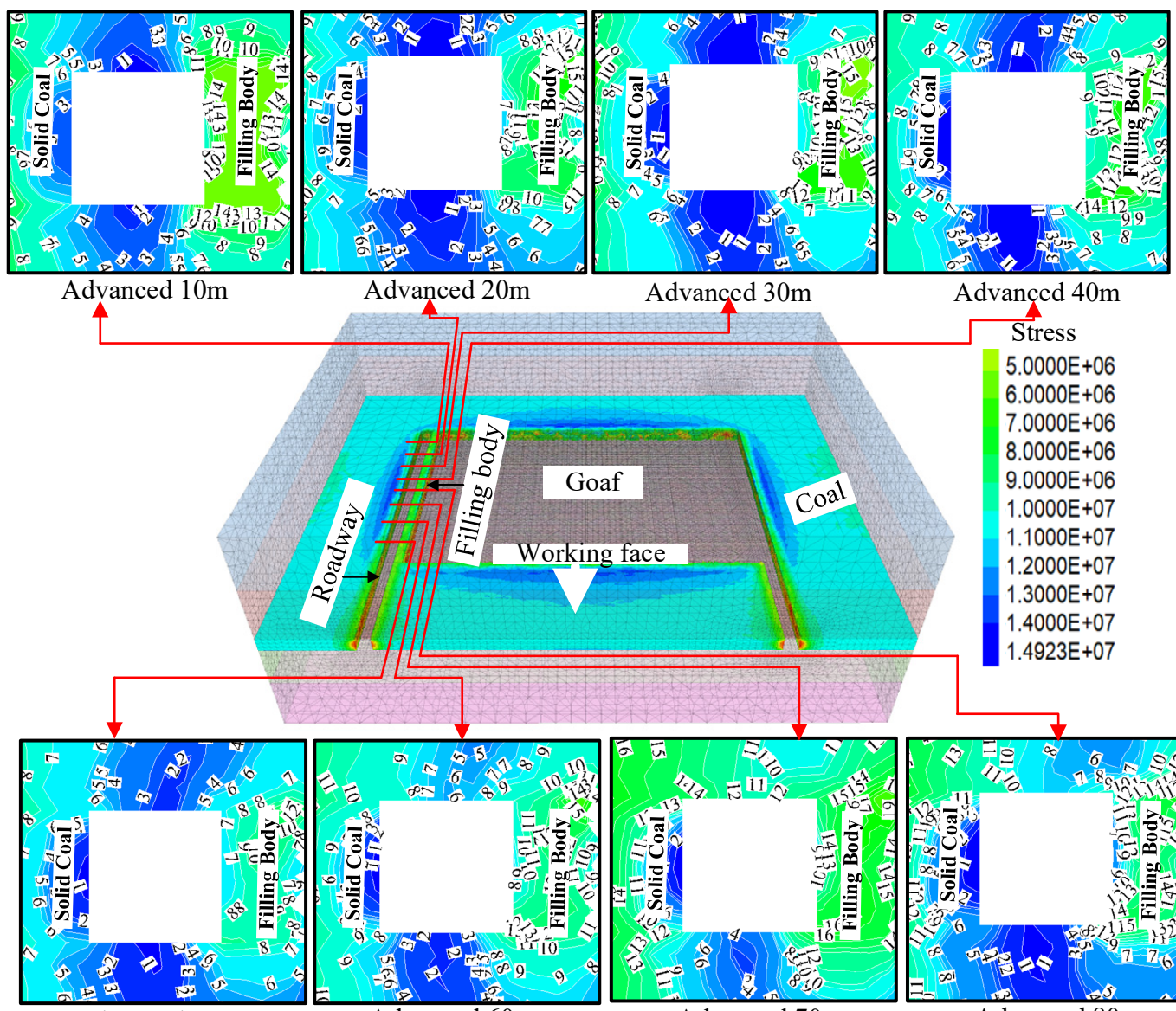

Advanced 20m

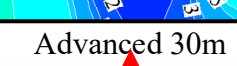

Advanced 40m Stress $5.0000 \mathrm{E}+06$ $6.0000 \mathrm{E}+06$ $7.0000 \mathrm{E}+06$ $8.0000 \mathrm{E}+06$ $9.0000 \mathrm{E}+06$ $1.0000 \mathrm{E}+07$ $1.1000 \mathrm{E}+07$ $1.2000 E+07$ $1.3000 \mathrm{E}+07$ $1.4000 \mathrm{E}+07$ $1.4923 E+07$

Advanced 50m

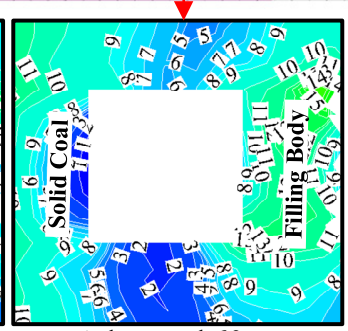

Advanced $60 \mathrm{~m}$

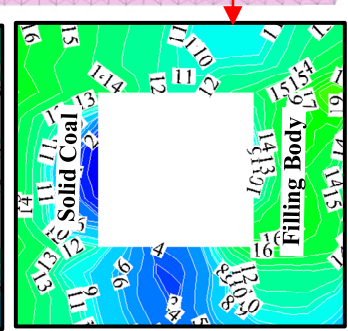

Advanced 70m

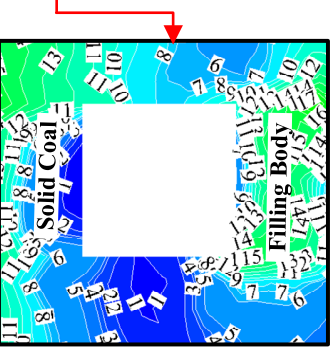

Advanced $80 \mathrm{~m}$

Fig. 7 Stress distribution of roadway surrounding rock in the early stage of working face advance.

\subsection{VARIATION CHARACTERISTICS OF SURROUNDING ROCK STRESS}

\subsubsection{EARLY STAGE OF WORKING FACE MINING}

The stress program of surrounding rock during working face mining is shown in Figure 7. It can be seen that the stress of the solid coal side and roof is large. The main reason is that the overlying strata bend and the basic roof is not fractured in the early stage of working face mining. At this time, the overlying strata of the roadway form a cantilever beam, and the stress mainly acts on the solid coal and the roof of the solid coal side.

\subsubsection{LATER STAGE OF WORKING FACE MINING}

In the later stage of working face mining, the overlying strata collapsed and the basic roof fractured. The stress distribution curve of solid coal and filling body is shown in Figure 8.

Figure 8(a) shows the variation curve between the stress acting on solid coal and the distance from the 


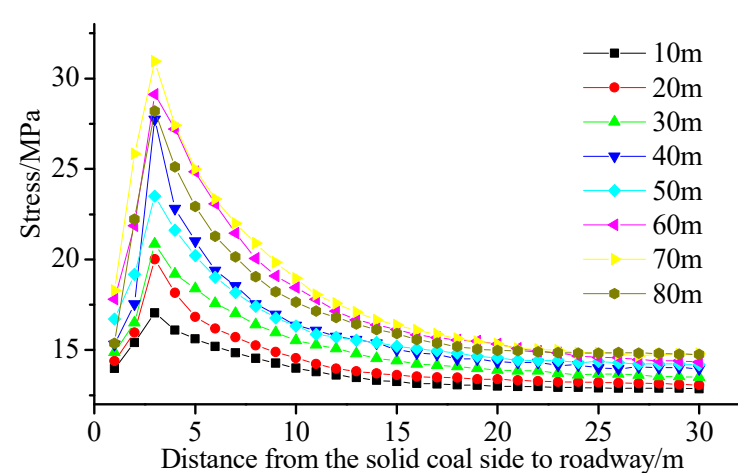

a) Stress distribution of solid coal

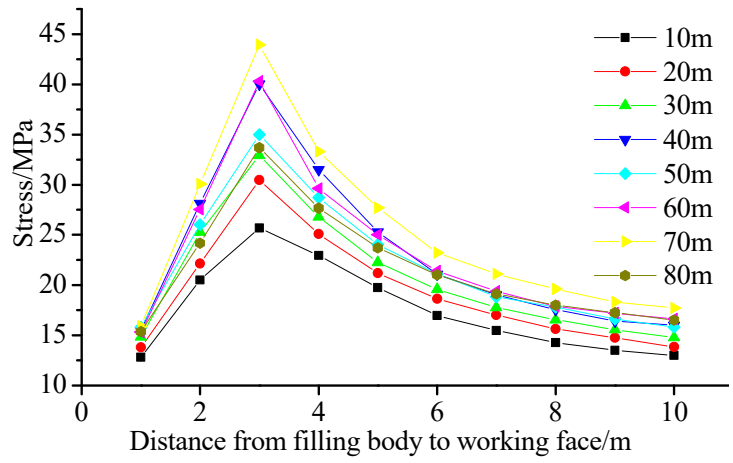

(b) Stress distribution of filling body

Fig. 8 Stress distribution on both sides of the roadway.

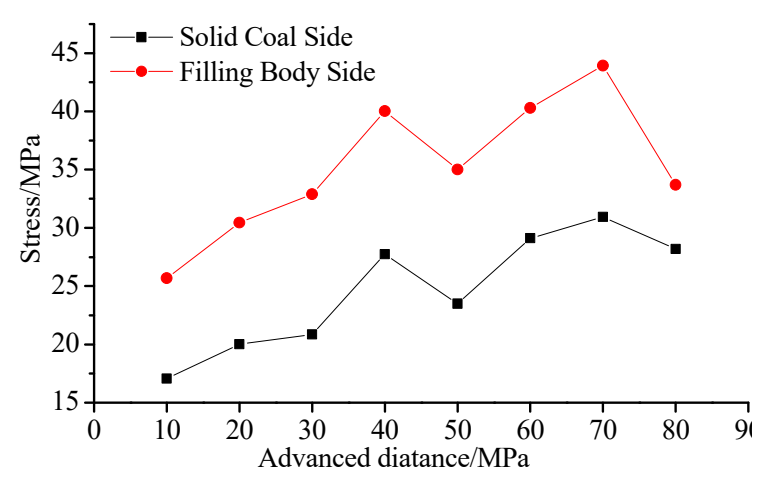

Fig. 9 Maximum stress distribution on both sides of the roadway.

solid to the roadway during mining. It can be seen that the stress acting on the solid coal increases first and then decreases due to the impact of the working face mining. The stress reaches the maximum at $3 \mathrm{~m}$ away from the roadway, and the stress gradually decreases with the distance from the roadway.

Figure $8(\mathrm{~b})$ shows the variation curve between the stress acting on the filling body and the distance from the filling body to the working face during mining. It can be seen that the stress acting on the filling body behind the working face also shows a variation trend of first increasing and then decreasing. The stress reaches the maximum at $3 \mathrm{~m}$ away from the working face, and the stress gradually decreases with the distance from the working face.

Figure 9 shows the maximum stress curve on both sides of the roadway during the working face mining. It can be seen from the figure that the stress acting on the filling body is higher than that acting on the solid coal. It is mainly due to the collapse of overlying strata and fracture of the basic roof in the later stage during working face mining, the stress mainly acts on the filling body and the roof of the filling body side.

With the working face mining forward, the stress on both sides gradually increases. When the working face advanced to $40 \mathrm{~m}$, the stress on the filling body and solid coal reached the first peak value, indicating that the working face has the first pressure. When the working face is advanced to $50 \mathrm{~m}$, the stress decreases obviously, which indicates that the overlying strata collapse and the stress acting on the overlying strata is released. During the working face advanced from $50 \mathrm{~m}$ to $70 \mathrm{~m}$, the stress on the filling body and solid coal gradually increased and reached the maximum when the advancing distance is $70 \mathrm{~m}$. It indicated that the periodic weighting step distance is reached at this time, which makes the stress concentration. When the working face is pushed forward to $80 \mathrm{~m}$, the stress decreases, which indicates that the stress concentration formed by periodic weighting is released.

According to the above analysis, it can be concluded that the stress acting on the filling body is greater than that acting on the solid coal, the first weighting step distance is $40 \mathrm{~m}$, and the periodic weighting step distance is $30 \mathrm{~m}$.

\subsection{VARIATION CHARACTERISTICS OF SURROUNDING ROCK DISPLACEMENT}

Figure 10 shows the variation of surrounding rock displacement during mining. It can be seen that when the working face advances $10 \mathrm{~m}$, the displacement of the surrounding rock is small. When the working face advanced from $20 \mathrm{~m}$ to $80 \mathrm{~m}$, the displacement of the roadway mainly concentrates on the filling body and the roadway roof on the side of the filling body. The displacement of solid coal and the roof of the solid coal side is small.

Figure 11 shows the deformation curve of the surrounding rock. With the working face advancing, the deformation of surrounding rock behind it gradually increases, and finally tends to be gentle. The deformation of the roadway roof is the largest, the deformation of two sides of the roadway is the second, and the deformation of the floor is the smallest.

The deformation characteristics of the roadway roof are as follows: the deformation of the roof on the side of the filling body is the largest, the roof in the middle of the roadway is the second, and the solid coal side is the smallest. 


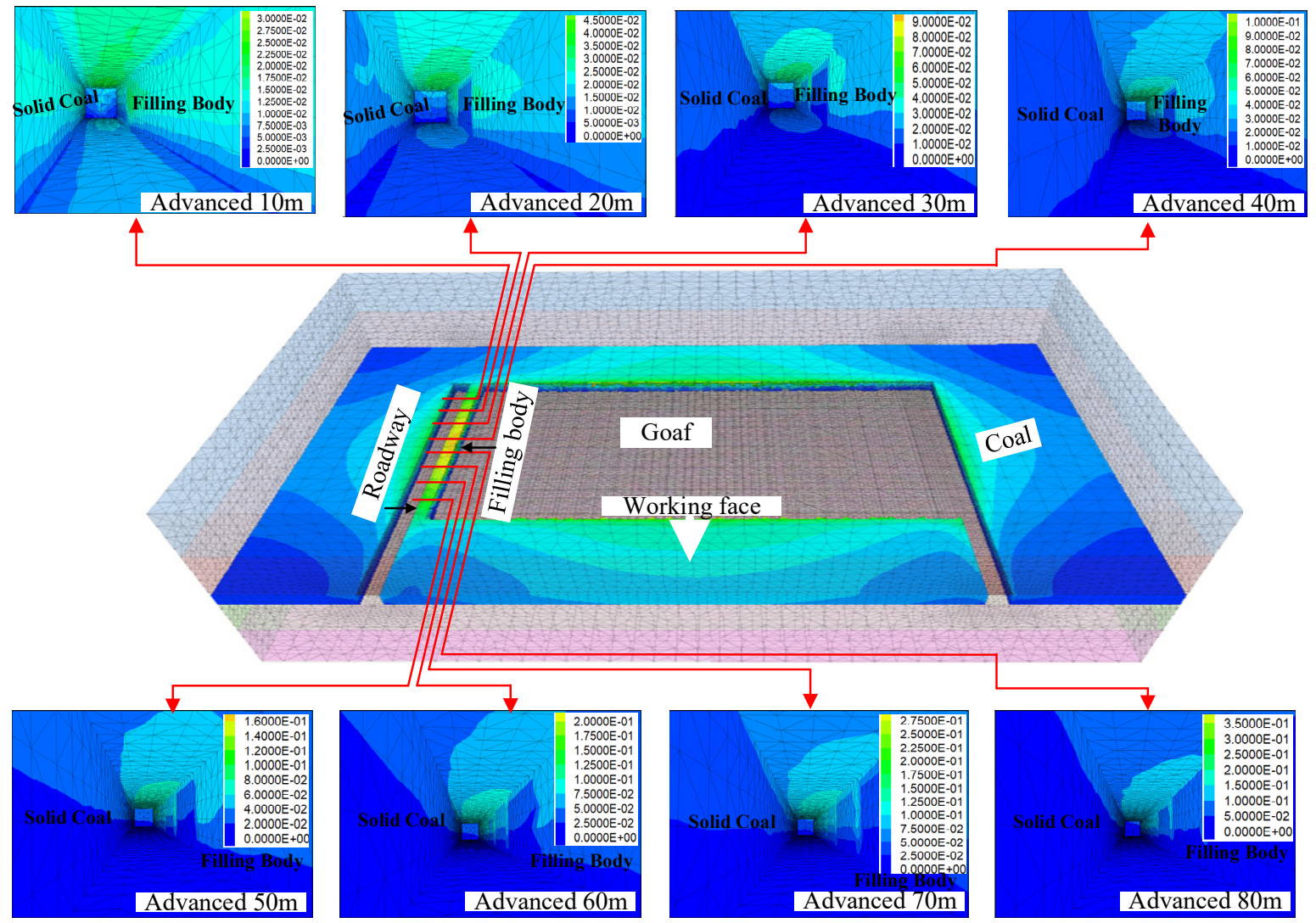

Fig. 10 Deformation characteristics of roadway surrounding rock.

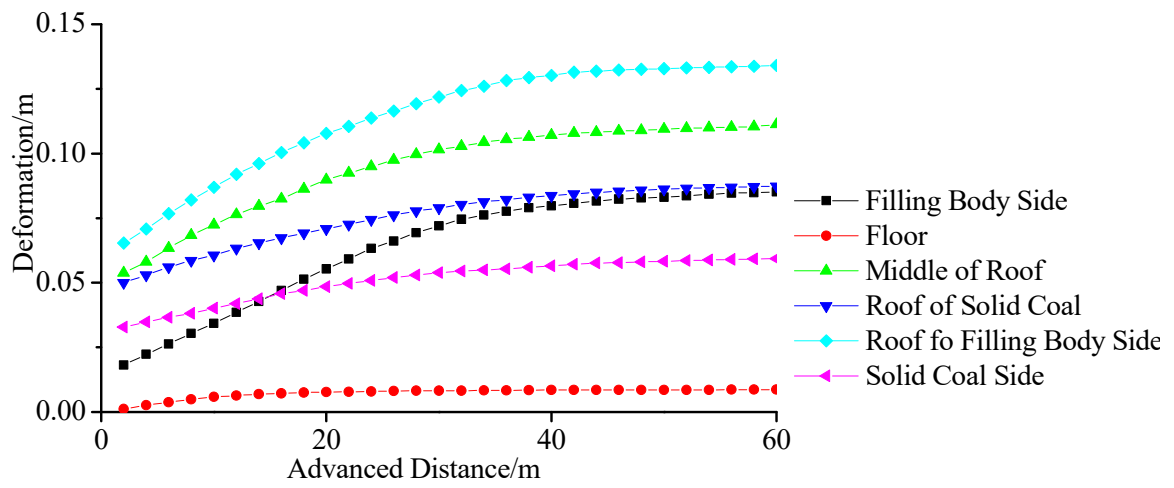

Fig. 11 Deformation of surrounding rock of roadway.

The deformation characteristics of the two sides of the roadway are as follows: when the working face advances $10 \mathrm{~m}$, the deformation of the solid coal side is large; when the working face advances $20-80 \mathrm{~m}$, the deformation of the filling body side is large.

\section{SURROUNDING ROCK CONTROL MECHANISM AND TECHNOLOGY \\ 4.1. SURROUNDING ROCK SUPPORTING MECHANISM}

The numerical simulation results show that the stress and displacement of the filling body and the roof on the side of the filling body are relatively large, while the stress and displacement of the solid coal and the roof on the side of solid coal are relatively small.
There is the obvious asymmetry in the roof, solid coal, and filling body. Therefore, it is necessary to strengthen the filling body and roof of the gob side entry retaining.

Because of this, the asymmetric coupling support technology of filling body + double row hydraulic prop combined with I-steel + high-strength pretension anchor cable + high-strength bolt is proposed. Figure 12 is the schematic diagram of asymmetric support.

On the filling body side: the double row hydraulic prop combined with I-steel is arranged along the filling body to strengthen support. Under the joint action of the hydraulic prop and filling body, the roof is broken along the edge of the filling body. The layout 


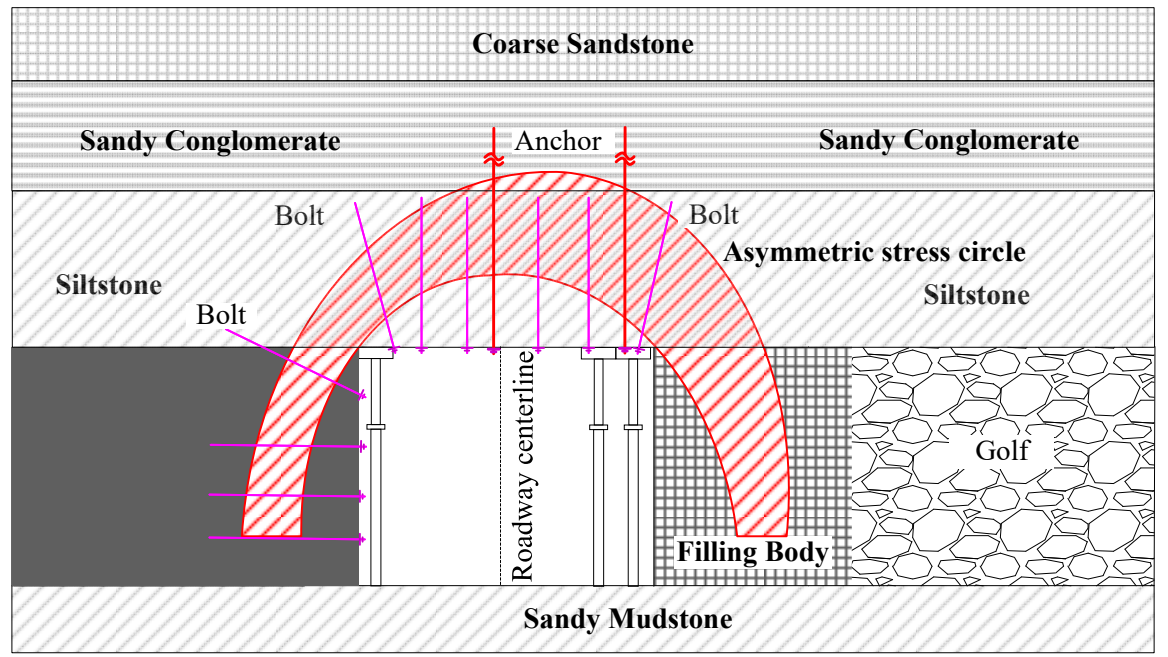

Fig. 12 Schematic diagram of asymmetric support.

of the double row hydraulic prop is equivalent to increasing the filling body width, which not only can improve the bearing capacity of the filling body, but also can bear part of the roof load. The double row hydraulic prop as the temporary reinforcement support of the filling body, can provide greater support resistance before the filling body forming and solidification, bear the roof load, control the separation layer between the direct roof and the basic roof, and the rotary deformation rate of the basic roof. Besides, the hydraulic prop has a certain degree of shrinkage, which can be coordinated with the rotation and deformation of the basic roof to avoid the phenomenon of roof penetration and floor-breaking.

The roof on the filling body side: high-strength pretension anchor cable + high-strength bolt + metal mesh support is used to connect the shallow main bearing structure formed by the bolt support and the second bearing structure formed by the anchor cable support to form the composite bearing structure of anchor cable and bolt. The formation of the composite bearing structure of anchor cable and bolt can effectively change the stress state of surrounding rock, inhibit the occurrence of bending deformation and tensile shear failure of surrounding rock, control the crack propagation, maintain the integrity of surrounding rock, ensure the effective transmission of support resistance, and improve the shear and bending performance of roof rock.

On the solid coal side: a single row of single hydraulic props are arranged along the solid coal to further strengthen the bearing capacity of the solid coal side.

The roof on the solid coal side: high-strength bolt + metal mesh support are used to effectively connect the overlying strata of the roadway and form a combination with the support structure of the roof on the filling bodyside to jointly maintain the stability of the roof.
Through the above support forms, the asymmetric stress circle is formed around gob side entry retaining, which can better reinforce surrounding rock.

\subsection{SUPPORT PARAMETERS}

The cross-section of the gob side entry retaining in No. 3 working face is rectangular, with the width $\times$ height $=4.0 \times 3.6 \mathrm{~m}$, and the strike length is $1583 \mathrm{~m}$. Based on the above analysis of gob side entry retaining with high water material, it is determined that the support form is: double row hydraulic prop combined with I-steel + high-strength pretension anchor cable + high-strength bolt + metal mesh. The roof adopts a high-strength bolt with parameters of $\Phi 20 \mathrm{~mm} \times 2400 \mathrm{~mm}$ and row spacing of $780 \times 850 \mathrm{~mm}$; the anchor cable adopts $1 \times 7$ strand steel strand of $\Phi 17.8 \mathrm{~mm} \times 7200 \mathrm{~mm}$, with a spacing of $2340 \mathrm{~mm} \times 850 \mathrm{~mm}$; the roadway side adopts twist bolt with parameters of $\Phi 18 \mathrm{~mm} \times 1800 \mathrm{~mm}$ and spacing of $800 \mathrm{~mm} \times 850 \mathrm{~mm}$.

The roadway support form and parameters are shown in Figure 13.

\subsection{ANALYSIS OF SUPPORT EFFECT}

The deformation of surrounding rock of gob side entry retaining in fully mechanized No. 3 working face is measured on-site, and the results are shown in Figure 14.

It can be seen that: when the working face advanced more than $0 \sim 30 \mathrm{~m}$, the roof sinks and the amount of movement on both sides increase rapidly. Over $30 \mathrm{~m}$, the moving speed gradually slows down, but the deformation still shows an increasing trend. When the working face advanced more than $50 \mathrm{~m}$, the displacement gradually tends to a stable value, the roof subsidence is $0.084 \mathrm{~m}$, the deformation of the filling body is $0.098 \mathrm{~m}$, and the deformation of the solid coal is $0.054 \mathrm{~m}$. Therefore, the above-mentioned support technology effectively limits the deformation of the 

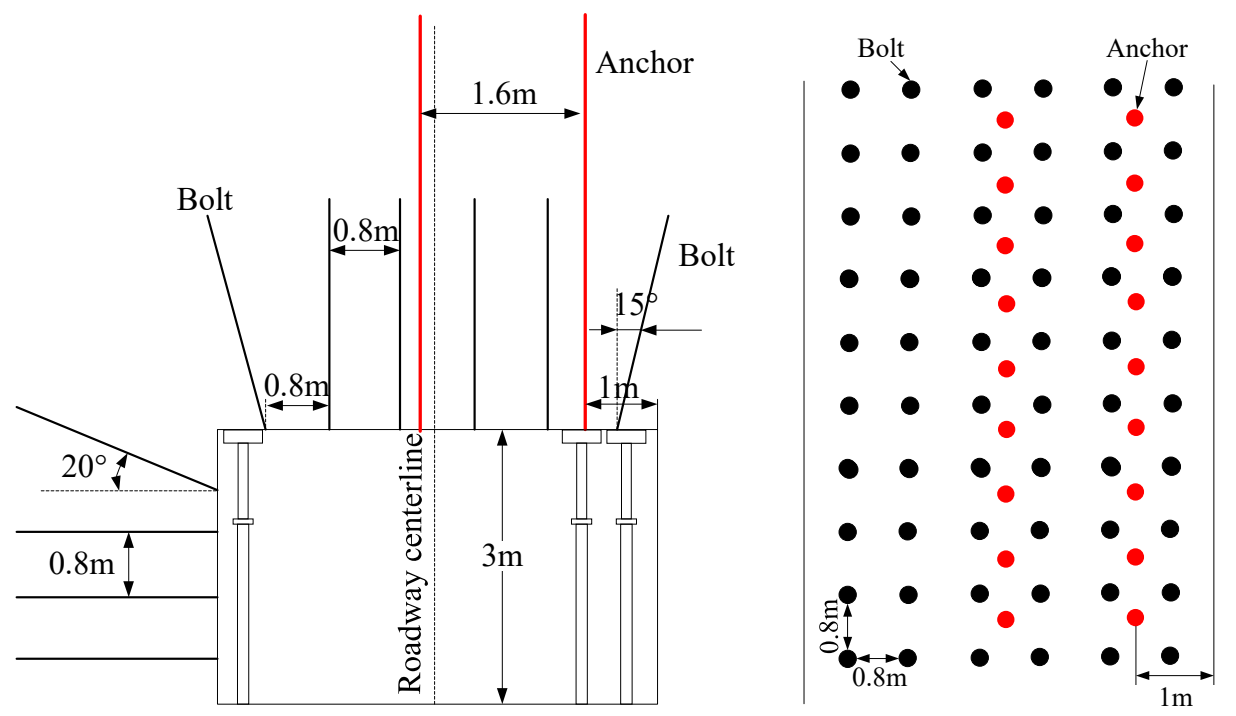

Fig. 13 Schematic diagram of roadway support.

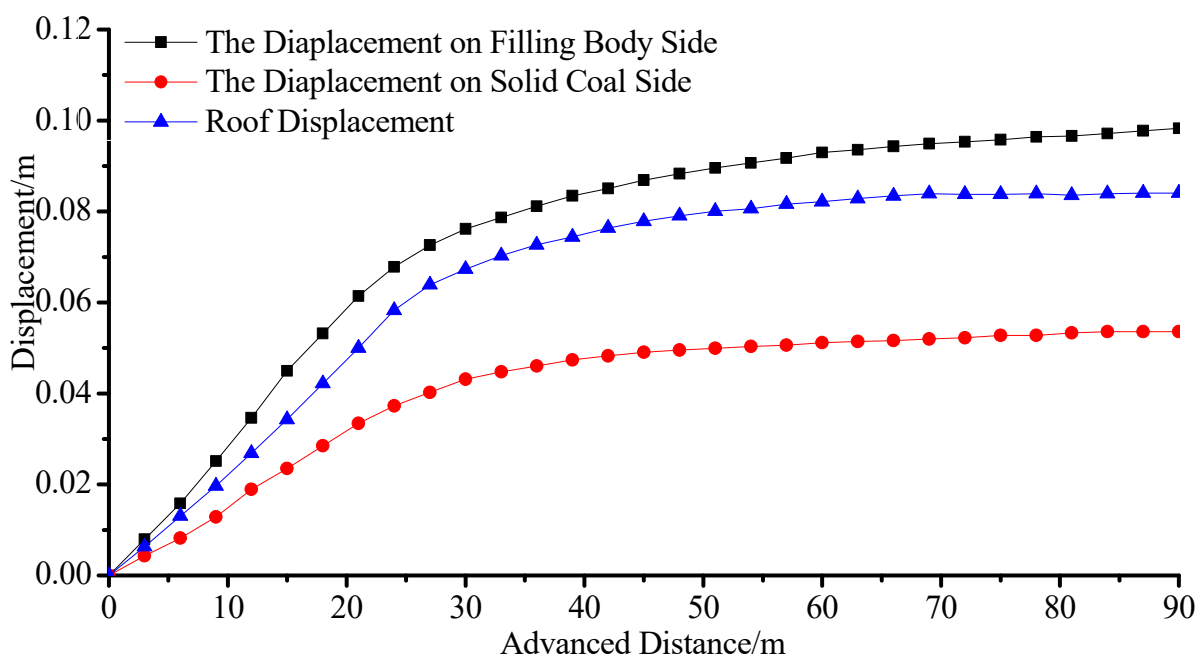

Fig. 14 Monitoring results of roadway surrounding rock.

surrounding rock of the gob side entry retaining roadway, and the roadway retaining test is successful.

Although the conclusions of this study play a certain guiding role on the coal mine site, they still have certain limitations. Mining in coal mines is a complex process of stress and displacement evolution, and the theoretical analysis and numerical simulation in this paper were all simplifications of complex engineering problems, the in-depth study of the stress and displacement of the surrounding rock of gob side entry retaining with high water content material is the content that the author will continue to study in the future. At the same time, the study of asymmetric support technology for different roadway surrounding rocks is also the content of further research in the future.

\section{CONCLUSION}

1. According to the stress variation of overlying strata during the mining process of the working face, the mechanical models before and after the basic roof fracture were established respectively, and the stress of surrounding rock of roadway was analyzed.

2. The stress of solid coal and filling body first increases and then decreases during the mining process of the working face, the stress on one side of the filling body of gob side entry retaining is greater than that of the solid coal side, the maximum stress is at $3 \mathrm{~m}$ away from the roadway.

3. During the working face mining, the stress and deformation of the filling body and the roof on the filling body side are large, the stress and deformation of the solid coal and the roof on the 
solid coal side are small. The first weighting step distance is $40 \mathrm{~m}$ and the periodic weighting step distance is $30 \mathrm{~m}$.

4. The stress and displacement of the surrounding rock of the roadway show an asymmetric state during mining. So, the asymmetric coupling support technology of filling body + double row hydraulic prop combined with I-steel + highstrength pretension anchor cable + high-strength bolt is put forward. The reliability of the coupling support technology is verified by field engineering practice, which provides a reference for support technology under similar engineering background.

\section{ACKNOWLEDGMENTS}

This study was supported by the Heilongjiang Provincial Natural Science Foundation of China (LH2020E121).

\section{REFERENCES}

Adhikary, D.P. and Guo, H.: 2015, Modelling of longwall mining-induced strata permeability change. Rock Mech. Rock Eng., 48, 1, 345-359.

DOI: $10.1007 / \mathrm{s} 00603-014-0551-7$

Altunbas, A., Soltanbeigi, B. and Cinicioglu, O.: 2017, Determination of active failure surface geometry for cohesionless backfills. Geomech. Eng., 12, 6, 9831001. DOI: $10.12989 /$ gae.2017.12.6.983

Bai, E.H., Guo, W.B., Tan, Y., Huang, G.S., Guo, M.J. and Ma, Z.B.: 2020, Roadway backfill mining with superhigh-water material to protect surface buildings: A case study. Appl. Sci.-Basel, 10, 1. DOI: 10.3390/app10010107

Chen, Y., Bai, J.B.,Yan, S., Xu, Y., Wang, X.Y. and Ma, S.Q.: 2012, Control mechanism and technique of floor heave with reinforcing solid coal side and floor corner in gob-side coal entry retaining. Int. J. Min. Sci. Technol., 22, 6, 841-845. DOI: $10.1016 /$ j.ijmst.2012.12.002

Chen, S.G., Hu, C. and Xiong, L.: 2012, A numerical study of goaf stability under a desert expressway. Advances in Discontinuous Numerical Methods and Applications in Geomechanics and Geoengineering, 289-294.

Retrieved from $<$ Go to ISI $>$ ://WOS:000329628600036

Chen, Y., Ma, S.Q., Yang, Y.G., Meng, N.K. and Bai, J.B.: 2019, Application of shallow-hole blasting in improving the stability of gob-side retaining entry in deep mines: A case study. Energies, 12, 19, 3623. DOI: $10.3390 /$ en 12193623

Doherty, P., Hasan, A., Suazo, G.H. and Fourie, A.: 2015, Investigation of some controllable factors that impact the stress state in cemented paste backfill. Can. Geotech. J., 52, 12, 1901-1912. DOI.: $10.1139 / \mathrm{cgj}-2014-0321$

Fallavena, V.L.V., Pires, M., Ferrarini, S.F. and Silveira, A.P.B.: 2018, Evaluation of zeolite/backfill blend for acid mine drainage remediation in coal mine. Energ. Fuel., 32, 2, 2019-2027.

DOI: 10.1021 /acs.energyfuels. $7 \mathrm{~b} 03322$
Gong, P., Ma, Z.G., Sun, J. and Zhang, R.R.: 2019, The blocking mechanism of the vertical feeding system of roadside support body material for backfilling gobside entry retaining. Adv. Civ. Eng. DOI: $10.1155 / 2019 / 6060197$

Guo, Z.B., Wang, Q., Li, Z.H., He, M.C., Ma, Z.B., Zhong, F.X. and Hu, J.: 2019, Surrounding rock control of an innovative gob-side entry retaining with energyabsorbing supporting in deep mining. Int. J. Low Carbon Technol., 14, 1, 23-35.

DOI: $10.1093 / \mathrm{ijl}$ lct/cty054

Han, C.L., Zhang, N., Ran, Z., Gao, R. and Yang, H.Q.: 2018, Superposed disturbance mechanism of sequential overlying strata collapse for gob-side entry retaining and corresponding control strategies. J. Cent. South Univ., 25, 9, 2258-2271. DOI: $10.1007 / \mathrm{s} 11771-018-3911-8$

Han, C.L., Zhang, N., Xue, J.H., Kan, J.G. and Zhao, Y.M.: 2019, Multiple and long-term disturbance of gob-side entry retaining by grouped roof collapse and an innovative adaptive technology. Rock Mech. Rock Eng., 52, 8, 2761-2773. DOI: $10.1007 / \mathrm{s} 00603-018-1612-0$

Huang, W.P., Wang, X.W., Shen, Y.S., Feng, F., Wu, K. and Li, C.L.: 2019, Application of concrete-filled steel tubular columns in gob-side entry retaining under thick and hard roof stratum: A case study. Energy Sci. Eng., 7, 6, 2540-2553. DOI: 10.1002/ese3.442

Haramy, K.Y. and Kneisley, R.O.: 1990, Yield pillars for stress control in longwall mines- case study. Geotech. Geol. Eng., 8, 4, 287-304. DOI: 10.1007/bf00920642

Li, H.M.: 2000, Control design of roof rocks for gob side entry. Chinese J. Rock Mech. Eng., 19, 651-654.

Li, H.Z., Guo, G.L. and Zhai, S.C.: 2016, Mining scheme design for super-high water backfill strip mining under buildings: a Chinese case study. Environ. Earth Sci., 75, 12, 1007. DOI: 10.1007/s12665-016-5837-5

Li, J.Z., Yin, Z.Q., Li, Y. and Li, C.M.: 2019, Waste rock filling in fully mechanized coal mining for goaf-side entry retaining in thin coal seam. Arab. J. Geosci., 12, 16. DOI: $10.1007 / \mathrm{s} 12517-019-4650-3$

Li, T., Chen, G.B., Qin, Z.C., Li, Q.H., Cao, B. and Liu, Y.L.: 2020, The gob-side entry retaining with the high-water filling material in Xin'an Coal Mine. Geomech. Eng., 22, 6, 541-552. DOI: 10.12989/gae.2020.22.6.541

Li, Y.G., Wang, W.X., Jin, L.Z., Wang, S. and Lu, J.: 2016, Study of roadside packing to go with gob-side entry retaining technology on crisp surrounding and blasting face in the Xinzhuang mine. Operational and Environmental Mine Health and Safety Practice and Innovation, 346-350. Retrieved from $<$ Go to ISI $>$ ://WOS:000410525800059

Liu, J.W., Sui, W.H., Zhang, D.Y. and Zhao, Q.J.: 2020, Durability of water-affected paste backfill material and its clean use in coal mining. J. Clean. Prod., 250, 119576. DOI: $10.1016 /$ j.jclepro.2019.119576

Liu, W.T., Pang, L.F., Xu, B.C. and Sun, X.: 2020, Study on overburden failure characteristics in deep thick loose seam and thick coal seam mining. Geomat. Nat. Haz. Risk, 11, 1, 632-653. DOI: $10.1080 / 19475705.2020 .1737584$ 
Ma, Z.G., Gong, P., Fan, J.Q., Geng, M.M. and Zhang, G.W.: 2011, Coupling mechanism of roof and supporting wall in gob-side entry retaining in fully-mechanized mining with gangue backfilling. Min. Sci. Technol. (China), 21, 6, 829-833.

Maleki, H.N., Agapito, J.F.T., Wangsgard M. and Cort, J.: 1986, Gate road layout design for two-seam longwall mining. Geotech. Geol. Eng., 4, 2, 111-127. DOI: $10.1007 / \mathrm{bf} 01560670$

Miao, X.X.: 2010, Review of research on mechanical behviors of ming rock mass and its related engineering technological innovation progress. Chinese J. Rock Mech. Eng., (in Chinese).

Skousen, J.: 2017, A methodology for geologic testing for land disturbance: Acid-base accounting for surface mines. Geoderma, 308, 302-311. DOI: 10.1016/j.geoderma.2017.07.038

Sun, Q., Zhang, J.X., Qi, W. and Li, M.: 2020, Backfill mining alternatives and strategies for mitigating shallow coal mining hazards in the western mining area of China. Q. J. Eng. Geol. Hydrogeol., 53, 2, $217-$ 226. DOI: $10.1144 /$ qjegh2017-026

Tang, J.X. and Zhang, Y.Q.: 2011, Analysis of the influence of the pressure-shear fault upon the mountain surface movement and deformation. Disaster Adv., 4, 98-102. Retrieved from $<$ Go to ISI $>$ ://WOS:000296486200016

Vadapalli, V.R., Gitari, M.W., Petrik, L.F., Etchebers, O. and Ellendt, A.: 2012, Integrated acid mine drainage management using fly ash. J. Environ. Sci. Health A Tox Hazard Subst. Environ. Eng., 47, 1, 60-69. DOI: $10.1080 / 10934529.2012 .629582$

Zhang, J.W. and Li, Y.L.: 2019, The stability of gob-side entry retaining in a high-gas-risk mine. Adv. Civ. Eng.. DOI: $10.1155 / 2019 / 7540749$

Zhang, N., Yuan, L., Han, C., Xue, J. and Kan, J.: 2012, Stability and deformation of surrounding rock in pillarless gob-side entry retaining. Saf. Sci., 50, 4, 593-599. DOI: 10.1016/j.ssci.2011.09.010

Zhang, Z.Z., Wang, W.J., Li, S.Q., Bai, J.B., Hao, S.P., Wu, H. and Yu, X.Y.: 2018, An innovative approach for gob-side entry retaining with thick and hard roof: A case study. Teh. Vjesn., 25, 4, 1028-1036. DOI: $10.17559 / \mathrm{Tv}-20160816155022$
Zhang, Z.Z., Yu, X., Wu, H. and Deng, M.: 2019, Stability control for gob-side entry retaining with supercritical retained entry width in thick coal seam longwall mining. Energies, 12, 7. DOI: 10.3390/en12071375

Zhao, H.: 2019, State-of-the-art of standing supports for gob-side entry retaining technology in China. J. S. Afr. I. Min. Metall., 119, 111, 891-906. DOI: $10.17159 / 2411-9717 / 17 / 449 / 2019$

Zhao, Z.M., Liu, Y.L. and Li, Y.: 2015, The study of application of high water material in filling mining technology. Proc. 2015 Asia-Pacific Energy Equipment Engineering Research Conference (Ap3er 2015), 9, 186-189. DOI: 10.2991/ap3er-15.2015.44 